\title{
PENERAPAN CORPORATE SOCIALRESPONSIBILITY (CSR) DALAM PERSPEKTIF ISLAM (Studi pada Program Kemitraan Bina Lingkungan PT Kertas Leces)
}

\author{
Trisnawati \\ Fakultas Ilmu Administrasi Universitas Brawijaya \\ Email: trisnawati@ub.ac.id
}

\begin{abstract}
Corporate Social Responsibility (CSR) or corporate social responsibility undertaken by PT Kertas Leces known as CSR (Community Development Partnership Program). This study used descriptive qualitative method, which the researchers suggested empirical problem at PT Kertas Leces beforehand which then became the basis of the holding of a study with a focus on the implementation of Corporate Social Responsibility (CSR) or Community Development Partnership Program (CSR) in the perspective of Islam. Based on the survey results revealed that the outputs or outcomes of its Corporate Social Responsibility (CSR) or Community Development Partnership Program (CSR) PT Kertas Leces are their environmental management work then fulfilled the rights of employees and their families, Small and Medium Enterprises (SMEs) or partner inmates who received soft loan can be independent and grow, their waste handling is good then created the environment around PT Kertas Leces, and their social investments PT Kertas Leces to the people around. In the Islamic perspective of what is done by PT Kertas Leces is appropriate, namely in terms of the values of (a) preservation of the environment and preserve it; (B) efforts to eradicate poverty; (C) putting something morally cleaner than morally dirty, although bringing greater profits; and (d) to be honest and trustworthy.
\end{abstract}

Keywords: CSR, welfare and islamic perspective

Di Indonesia sendiri praktek CSR sudah banyak dilakukan misalnya dalam bidang pendidikan, lingkungan, dan kesehatan. Diantaranya pelaksanaan program tanggung jawab sosial perusahaan adalah Corporate Social Responsibility (CSR) PT Bank Negara Indonesia, Tbk. Meskipun oleh pemerintah telah diatur mengenai CSR ini, tetapi masih ada saja perusahaan yang sedikit dan bahkan tidak memberikan kontribusinya terhadap masyarakat dan lingkungan. Salah satunya adalah Corporate Social Responsibility (CSR) PT Bank Rakyat Indonesia.

Pelaksanaan program CSR oleh BUMN akan memberikan manfaat positif terhadap perusahaan, terutama dalam jangka panjang. Selain menegaskan brand differentiation perusahaan, CSR juga berfungsi sebagai sarana untuk memperoleh license to operate, baik dari pemerintah maupun masyarakat. CSR juga bisa berfungsi sebagai strategi risk management perusahaan. Corporate Social Responsibility (CSR) milik BUMN adalah Program Kemitraan dan Bina Lingkungan (PKBL). Dalam UU BUMN dinyatakan bahwa selain mencari keuntungan, peran BUMN adalah juga memberikan bimbingan bantuan secara aktif kepada pengusaha golongan lemah, koperasi dan masyarakat. Peraturan Menteri Negara BUMN menjelaskan bahwa sumber dana PKBL berasal dari penyisihan laba bersih perusahaan sebesar $2 \%$ yang dapat digunakan untuk Program Kemitraan ataupun Bina Lingkungan. Peraturan ini juga menegaskan bahwa pihak-pihak yang berhak mendapat pinjaman adalah pengusaha beraset bersih maksimal Rp 200 juta atau beromset paling banyak Rp 1 miliar per tahun (http://www.csrreview-online.com/)

Untuk melaksanakan PKBL diantaranya pemerintah harus melakukan semacam dialog atau interaksi dengan masyarakat. Penerapan PKBL semacam ini terlihat dalam program-program pengembangan dan pemberdayaan komunitas masyarakat oleh berbagai perusahaan BUMN. Kegiatan ini lebih dikenal dengan istilah Pengembangan Komunitas atau Community Development (CD). Bentuk kegiatan yang dilakukan oleh BUMN antara lain ditujukan bagi korban bencana alam, pendidikan dan pelatihan, peningkatan kesehatan, pengembangan prasarana dan sarana umum, serta sarana ibadah. Jenis-jenis kegiatan Pengembangan Komunitas masyarakat oleh BUMN ada bermacam-macam. Tergantung situasi dan 
kebutuhan dari masyarakat sekitar, di mana BUMN tersebut berada.

Salah satu perusahaan Negara atau BUMN di Indonesia adalah PT Kertas Leces. Perusahaan PT Kertas Leces ini terletak di Kabupaten Probolinggo, Jawa Timur. Perusahaan ini memiliki Instalasi Pengolahan Air Limbah (IPAL), di tempat ini semua limbah diolah kemudian dapat langsung dipergunakan petani untuk pengairan sawah sekaligus dapat meningkatkan hasil pertanian. Hal ini sebagai wujud tanggung jawab sosial perusahaan PT Kertas Leces pada pelestarian lingkungan. Tetapi yang menjadi masalah mendasar adalah kondisi perusahaan yang saat ini labil. PT Kertas Leces pada tahun-tahun terakhir ini jarang mendapatkan laba dan sejak bulan Juni 2010 kemarin perusahaan PT Kertas Leces mengalami ketidakstabilan di mana perusahaan kurang lancar dalam hal beroperasi, bahkan sempat beredar berita di kalangan masyarakat bahwa PT Kertas Leces akan gulung tikar. Apakah dengan keadaan yang kurang stabil ini, PT Kertas Leces masih melaksanakan Corporate Social Responsibility (CSR) sebagai bentuk tanggung jawab sosialnya terhadap masyarakat dan lingkungan.

Dari uraian diatas maka penulis tertarik untuk meneliti mengenai Corporate Social Responsibility $(C S R)$ pada perusahaan PT Kertas Leces. Untuk itu penulis mengambil judul Penerapan Corporate Social Responsibility $(C S R)$ pada PT Kertas Leces (Studi Pada Program Kemitraan Bina Lingkungan PT Kertas Leces). Mengingat bahwa setiap perusahaan terutama perusahaan yang memakai sumber daya alam sebagai bahan baku industri maupun bahan bakar industrinya, memiliki dampak yang sangat besar terhadap masyarakat dan lingkungan disekitar tempat berdirinya perusahaan itu. Karenanya setiap perusahaan memiliki kewajiban dan bahkan harus secara sukarela melakukan Corporate Social Responsibility (CSR) sebagai bentuk pertanggungjawaban atas dampak yang ditimbulkan oleh aktivitas perusahaannya. Berdasarkan latar belakang diatas maka penelitian ini akan membahas tentang bagaimanakah penerapan Corporate Social Responsibility (CSR) pada PT Kertas Leces dalam perspektif Islam?

\section{Corporate Social Responsibility (CSR)}

\section{Pengertian Corporate Social Responsibility (CSR)}

Definisi CSR (Corporate Social Responsibility) menurut Lawrence, Weber, dan Post (2005) dalam Kartini (2009:6) adalah "CSR means that a corporation should be held accountable for any of its actions that affect people, their communities, and their environment." (CSR diartikan bahwa sebuah perusahaan seharusnya membangun akuntabilitas untuk tindakan yang mempengaruhi masyarakat, komunitas di sekitar perusahaan, dan lingkungan di sekitar perusahaan)

Menurut The World Business Council for Sustainable Development (WBCSD) dalam Wibisono (2007:7) pengertian Corporate Social Responsibility (CSR) adalah Corporate Social Responsibility (CSR) sebagai komitmen dunia usaha untuk terus menerus bertindak secara etis, beroperasi secara legal dan berkontribusi untuk peningkatan ekonomi, bersamaan dengan peningkatan kualitas hidup dari karyawan dan keluarganya sekaligus juga peningkatan kualitas komunitas lokal dan masyarakat luas.

Penerapan dari konsep Good Corporate Governance $(G C G)$ sebagai tata kelola perusahaan yang baik bertanggung jawab terhadap masyarakat dan lingkungannya. Dampak dari penerapan Good Corporate Governance ( $G C G$ ) yaitu diterapkannya Corporate Social Responsibility (CSR). Penerapan Corporate Social Responsibility (CSR) ini termasuk dalam penerapan prinsip responsibilitas (responsibility) dari perusahaan.

\section{Bentuk-bentuk Corporate Social Responsibility (CSR)}

Dalam penerapannya secara ringkas bentuk Corporate Social Responsibility (CSR) dapat digolongkan dalam 4 bentuk yaitu: (1) Pengelolaan lingkungan kerja secara baik, termasuk didalamnya penyediaan lingkungan yang aman dan nyaman, sistem kompensasi yang layak dan perhatian terhadap kesejahteraan karyawan dan keluarganya; (2) Kemitraan antara perusahaan dan masyarakat, khususnya masyarakat lokal. Kemitraan ini diwujudkan secara umum dalam program Community Development (CD) untuk membantu meningkatkan kesejahteraan umum masyarakat setempat dalam kurun waktu yang cukup panjang. Melalui program ini, diharapkan masyarakat akan menerima manfaat keberadaan perusahaan yang digunakan untuk menopang kemandiriannya bahkan setelah perusahaan berhenti beroperasi; (3) Penanganan kelestarian lingkungan, kegiatan ini dimulai dari lingkungan perusahaan sendiri, termasuk melakukan penghematan penggunaan listrik, air, kertas, dan lain sebagainya sampai penanganan limbah akibat kegiatan perusahaan, agar tidak mencemari lingkungan sekitar kantor, pabrik dan atau lahan; dan (4) 
Investasi sosial yang sering kali diartikan secara sempit sebagai "kegiatan amal perusahaan". Makna sesungguhnya adalah perusahaan memberi dukungan finansial dan non-finansial terhadap kegiatan sosial dan lingkungan yang dilakukan oleh kelompok/organisasi lain yang pada akhirnya akan menunjang kegiatan bisnis perusahaan. Karena perusahaan melalui investasi sosial akan dapat menuai citra yang positif (corporate image). (Wahyudi dan Azheri, 2008:6263)

\section{Program TanggungJawabSosial Perusahaan (CSR)}

Bentuk program TanggungJawab Sosial Perusahaan (CSR) antara lain: (1) Community Relation, kegiatan ini menyangkut pengembangan kesepahaman melalui komunikasi dan informasi kepada para pihak yang terkait. Beberapa kegiatan yang dilakukan PLN antara lain: melaksanakan sosialisasi instalasi listrik; (2) Community Services, program bantuan dalam kegiatan ini berkaitan dengan pelayanan masyarakat atau kepentingan umum. Kegiatan yang dilakukan selama tahun 2011, antara lain memberikan Bantuan bencana alam; (3) Community Empowerint, kegiatan ini terdiri dari program-program yang memberikan akses yang lebih luas kepada masyarakat untuk menunjang kemandiriannya.

\section{CSR Dalam Perspektif Islam}

\section{Pandangan Islam terhadap Tanggung Jawab Sosial Perusahaan}

Menurut Sayyid Qutb, Islam mempunyai prinsip pertanggungjawaban yang seimbang dalam segala bentuk dan ruang lingkupnya. Antara jiwa dan raga, antara individu dan keluarga, antara individu dan sosial dan, antara suatu masyarakat dengan masyarakat yang lain. Tanggung jawab sosial merujuk pada kewajiban-kewajiban sebuah perusahaan untuk melindungi dan memberi kontribusi kepada masyarakat dimana perusahaan itu berada. Tanggung jawab sosial merujuk pada kewajiban-kewajiban sebuah perusahaan untuk melindungi dan memberi kontribusi kepada masyarakat dimana perusahaan itu berada. Sebuah perusahaan mengemban tanggung jawab sosial dalam tiga domain: (1) Pelaku-Pelaku Organisasi , meliputi: hubungan perusahaan dengan pekerja (QS. An-nisa ayat 149), hubungan pekerja dengan perusahaan dan hubungan perusahaan dan pelaku usaha lain; distributor, konsumen, pesaing; (2) Lingkungan alam (QS.
Al-A'raf ayat 56); dan (3) Kesejahteraan sosial masyarakat

Islam mempunyai prinsip pertanggungjawaban yang seimbang dalam segala bentuk dan ruang lingkupnya. Antara jiwa dan raga, antara individu dan keluarga, antara individu dan sosial dan, antara suatu masyarakat dengan masyarakat yang lain. Tanggung jawab sosial merujuk pada kewajiban-kewajiban sebuah perusahaan untuk melindungi dan memberi kontribusi kepada masyarakat dimana perusahaan itu berada. Sebuah perusahaan mengemban tanggung jawab sosial dalam tiga domain:

Pelaku-Pelaku Organisasi, meliputi:

\section{a. Perusahaan dengan Pekerja (QS. An-nisa ayat 149)}

Dalam wilayah non-Islam, standar etis seringkali ditentukan oleh perilaku para manajer. Standar ini meliputi perekrutan dan pemecatan, upah, pelecahan seksual, dan hal-hal lain yang relevan dengan kondisi kerja sesorang. Adapun kegiatan berupa: (1) Keputusan perekrutan, promosi dan lain-lain bagi pekerja. Islam mendorong kita untuk memperlakukan setiap Muslim secara adil. sebagai contoh, dalam perekrutan, promosi atau keputusan-keputusan lain di mana seorang manajer harus menilai kinerja seseorang terhadap orang lain, kejujuran dan keadilan ('adl) adalah sebuah keharusan. Allah SWT mempertahankan kita untuk melakukan hal ini: "sesungguhnya Allah SWT menyuruh kamu menyampaikan amanat kepada yang berhak menerimanya, dan apabila menetapkan hukum di antara manusia supaya kamu menetapkan dengan adil"; (2) Upah Yang Adil, Ibn Taymiyah menyatakan bahwa seorang majikan memiliki kewajiban untuk membayar upah yang adil kepada para pekerjanya. Sejumlah majikan mungkin mengambil keuntungan dari para pekerjanya dan membayar rendah kepada mereka karena tuntutan kebutuhan mereka untuk mendapat penghasilan. Jika tingkat upah terlalu rendah, para pekerja mungkin tidak termotivasi untuk berusaha secara maksimal. Sama halnya, jika tingkat upah terlalu tnggi, sang majikan mungkin tidak mendapatkan keuntungan dan tidak dapat menjalanjan perusahaannya. (3) Penghargaan terhadap keyakinan pekerja, prinsip umum tauhid atau keesaan berlaku untuk semua aspek hubungan antara perusahaan dan pekerjaanya. Pengusaha Muslim tidak boleh memperlakukan pekerjaanya seolah-olah Islam tidak berlaku selama waktu kerja. Sebagai contoh, pekerja Muslim harus diberi waktu untuk 
melaksanakan shalat, tidak boleh dipaksa untuk melakukan tindakan yang bertentangan dengan aturan moral Islam, harus diberi waktu istirahat bila mereka sakit dan tidak dapat bekerja, serta tidak boleh dilecehkan secara seksual, dan lain-lain. Untuk menegakkan keadilan dan keseimbangan, keyakinan para pekerja non-Muslim juga harus dihargai. "Allah SWT tiada melarang kamu untuk berbuat baik dan berlaku adil terhadap orang-orang yang tiada memerangimu karena agama dan tidak pula mengusir kamu dari negerimu. Sesungguhnya Allah SWT menyukai orang-orang yang berlaku adil"; (4) Akuntabiitas, meskipun majikan atau pekerja dapat secara sengaja saling menipu satu sama lain, namun mereka berdua harus mempertanggungjawabkan perbuatanya di depan Allah SWT. Sebagai contoh, Rasulullah Saw tidak pernah menahan upah siapapun; (5) Kebajikan, prinsip kebajikan (Ihsan) seharusnya merasuk dalam hubungan antara bisnis dan pekerja. Pada suatu saat, sebuah usaha mungkin berjalan kurang memuaskan, dan para pekerjanya mungkin akan menanggung pengurangan upah sementara untuk waktu kerja yang sama. Aspek lain prinsip kebajikan adalah tidak melakukan tekanan yang tidak melakukan tekanan yang tidak semestinya terhadap para pekerja untuk bekerja secara membabi buta.

\section{b. Hubungan Pekerja dengan Perusahaan}

Berbagai persoalan etis mewarnai hubungan antara pekerja dengan perusahaan, terutama berkaitan dengan persoalan kejujuran, kerahasiaan, dan konflik kepentingan. Dengan demikian, seorang pekerja tidak boleh menggelapkan uang perusahaan, dan juga tidak boleh membocorkan rahasia perusahaan kepada orang luar. Praktek tidak etis lan terjadi ketika para manajer menambahkan harga palsu untuk makanan dan pelayanan lain dalam pembukuan keuangan perusahaan mereka. Beberapa dari mereka melakukan penipuan karena merasa dibayar rendah, dan ingin mendapatkan upah yang adil. pada saat yang lain, hal ini dilakukan semata karena ketamakan. Pekerja Muslim, seharusnya tidak berbuat sesuatu dengan cara-cara yang tidak etis.

\section{c. Hubungan Perusahaan dan Pelaku Usaha Lain}

Halin terkait dengan: (1) Pemasok Berkaitan dengan pemasok, Etika bisnis menyatakan bahwa seseorang harus melakukan negosiasi dengan harga yang adil, dan menghindari kesalahpahaman dimasa depan, serta mengadakan perjanjian dengan tertulis; (2) Pembeli/konsumen Pembeli segarusnya menerima barang dalam kondisi baik dan dengan harga yang wajar, mereka juga harus diberitahu bila terdapat kekurangan-kekurangan pada suatu barang. Islam melarang praktek-praktek ketika berhubungan dengan konsumen atau pembeli, seperti: Dilarang mengunakan alat ukur yang tidak tepat; Dilarang Penimbunan dan manipulasi; Dilarang Penjualan barang yang rusak atau palsu; Dilarang menjual barang-barang curian; Dilarang mengambil bunga dan riba; Dilarang bersupah palsu dalam keputusan menjual baranga palsu; (3) Masyarakat umum Seorang pengusaha memiliki kewajiban khusus jika ia menyediakan barang kebutuhan penting bagi masyarakat. Dalam menetapkan harganya dengan harga yang wajar, seperti pupuk bagi petani, dan obatan-obatan untuk petani, jadi dilarang untuk melakukan pengontrolan harga; (4) Pihak yang berkepentingan/pemilik/Mitra Yaitu dengan kegiatankegiatan yang menguntungkan individu atau masyarakat dan menghapus kejahatan adalah tindakan yang luhur. Islam mendorong terwujudnya hubungan kemitraan seperti, Mudharabah, Musyarakah, Murabahah, dan Qard Hasan; (5) Fakir Miskin Pengusasaha akan selalu didekati oleh kaum fakir miskin utuk meminta sedekah. Janganlah memberikan sesuatu yang akan membuat fakir miskin itu akan tambah menderita (seperti barang barang siasa yang akan membahaykan fakir miskin itu seperti makanan rusak. Para pengusaha muslim harus memberikan kepada kaum miskin apa yang baik dan diperoleh dengan cara yang halal; (6) Pesaing Persaingan dengan mengeliminasi para pesaing dengan harapan meproleh hasil ekonomi diatas rata-rata, sehingga terjadi praktek penimbunan dan monopoli, perbuatan tersebut dilarang Islam.

\section{d. Hubungan dengan Lingkungan Alam (QS. Al-A'raf aya $t$ 56)}

Perusahan dilarang membuang produk limbahnya mereka ke udara, sungai dan tanah. Hal ini kan menyebabkan tejadinya fenomena hujan asam, pemanasan global, dan ternacuni rantai makanan. Seoarang pengusaha islam diharapkan memlihara lingkungan alamnya seperti perlakuan terhadap binatang, seperti contoh seorang muslim dilarang untuk mengikat kaki binatng, lalu menyeretnya untuk disemblih/dipotong. Kemudian juga polusi lingkungan dan hak kepemilikan, Sekali seorang muslim mencemari lingkungan, ia diharuskan membersihkannya atau memindahkannya 
apa yang menjadi pencemaran tersebut. Polusi Lingkungan dan Sumber Daya Bebas. Jika terjadi pencemaran atau gangguan dalam bentuk apapun, maka pihak pihak yang bersalah harus bertanggung jawab dengan membersihkannya sendiri ataupun dengan mengakhiri penyebab masalah tersebut. d. Kesejahteraan Sosial secara Umum. Sebagai bagian masyarakat, pengusaha muslim harus turut memperhatikan kesejahteraan anggotanya yang miskin dan lemah.

\section{e. Kesejahteraan Sosial Masyarakat}

"bukanlah menghadapkan wajahmu ke arah timur dan barat itu suatu kebajikan, akan tetapi Sesungguhnya kebajikan itu ialah beriman kepada Allah, hari Kemudian, malaikat-malaikat, kitab-kitab, nabi-nabi dan memberikan harta yang dicintainya kepada kerabatnya, anak-anak yatim, orang-orang miskin, musafir (yang memerlukan pertolongan) dan orang-orang yang meminta-minta; dan (memerdekakan) hamba sahaya, mendirikan shalat, dan menunaikan zakat; dan orang-orang yang menepati janjinya apabila ia berjanji, dan orang-orang yang sabar dalam kesempitan, penderitaan dan dalam peperangan. mereka Itulah orang-orang yang benar (imannya); dan mereka Itulah orang-orang yang bertakwa". (QS. Al Baqarah:177)

Dari ayat di atas dapat diambil kesimpulan bahwa Islam adalah agama yang mengedepankan pentingnya nilai-nilai sosial di masyarakat ketimbang hanya sekedar menghadapkan wajah kita ke barat dan ke timur dalam shalat. Tanpa mengesampingkan akan pentingnya shalat dalam Islam, Al Quran mengintegrasikan makna dan tujuan shalat dengan nilai-nilai sosial. Di samping memberikan nilai keimanan berupa iman kepada Allah SWT, Kitab-Nya, dan Hari Kiamat, Al Quran menegaskan bahwa keimanan tersebut tidak sempurna jika tidak disertai dengan amalan-amalan sosial berupa kepedulian dan pelayanan kepada kerabat, anak yatim, orang miskin, dan musafir serta menjamin kesejahteraan mereka yang membutuhkan.

Tujuan dan nilai-nilai dalam ekonomi Islam antara lain: kesejahteraan ekonomi dalam kerangka normanorma moral Islam, persaudaraan dan keadilan universal, distribusi pendapatan yang adil dan kebebasan individu dalam konteks kesejahteraan sosial.

Beberapa prinsip Islam dalam menjalankan bisnis yang berkaitan dengan CSR antara lain: menjaga lingkungan dan melestarikannya (Surat Al-Maidah ayat 32), upaya untuk menghapus kemiskinan (Surat Al-Hasyr ayat 7), mendahulukan sesuatu yang bermoral bersih daripada sesuatu yang secara moral kotor, walaupun mendatangkan keuntungan yang lebih besar (Surat Al-Maidah ayat 103) dan Jujur dan amanah (Surat Al-Anfal ayat 27)

\section{METODE PENELITIAN}

Jenis penelitian yang digunakan dalam penelitian ini adalah jenis penelitian deskriptif dengan menggunakan pendekatan kualitatif. Diungkapkan oleh Bogman dan Taylor dalam buku karya Moleong (2009:3) yang menyatakan bahwa metodologi kualitatif adalah prosedur penelitian yang menghasilkan data deskriptif berupa kata-kata tertulis atau lisan dari orang-orang dan perilaku yang diamati.

Lokasi penelitian disini yang dimaksud adalah tempat dimana peneliti melakukan penelitian terhadap obyek yang diteliti, maka lokasi penelitian yang dipilih peneliti adalah pada Kabupaten Probolinggo. Karena salah satu misi daerah ini adalah mewujudkan kesejahteraan masyarakat melalui peningkatan daya saing daerah, pertumbuhan ekonomi berbasis kerakyatan, dan optimalisasi pengelolaan sumber daya yang berkelanjutan. Jadi dapat disimpulkan bahwa Kabupaten ini lebih menekankan pada peningkatan di bidang industrinya. Hal ini dapat dibuktikan dengan adanya beberapa perusahaan besar yang beroperasi di Kabupaten Probolinggo, seperti Perusahaan Listrik Negara (PLN) yang memasok listrik ke berbagai wilayah Jawa dan sekitarnya, dan juga terdapat perusahaan PT Kertas Leces yang telah memiliki image sampai pada tingkat internasional.

\section{HASIL DAN PEMBAHASAN}

Dari penelitian yang telah dilakukan, maka data yang diperoleh dapat dianalisis mengenai bagaimana penerapan Corporate Social Responsibility (CSR) pada PT Kertas Leces. Corporate Social Responsibility $(C S R)$ perusahaan PT Kertas Leces ini dikenal dengan nama Program Kemitraan Bina Lingkungan (PKBL). Organisasi pelaksana program Corporate Social Responsibility (CSR) pada PT Kertas Leces dibagi menjadi dua bagian yaitu Departemen Penelitian dan Pengembangan (Litbang) dan Sub Unit Hubungan Masyarakat (Humas).

Departemen Penelitian dan Pengembangan (Litbang) menangani Program Kemitraan, sedangkan Sub Unit Hubungan Masyarakat (Humas) menangani Program Bina Lingkungan atau di PT Kertas Leces disebut Community Development (CD). Masingmasing bagian memiliki tupoksi (tugas, pokok dan 
fungsi) dan program kerja yang berbeda. Departemen Litbang memiliki program kerja untuk melaksanakan Program Kemitraan yang selalu bersinggungan langsung dengan para calon mitra binaan dan mitra binaan yang sudah menjalin kemitraan dengan PT Kertas Leces. PT Kertas memulai Program Kemitraan Bina Lingkungan pada tahun 1990 yaitu pada saat perusahaan mendapatkan laba dan menyisihkan bagian laba sebesar Rp 200.000.000,00 untuk pelaksanaan Program Kemitraan, keputusan ini berdasarkan Keputusan Direksi PT Kertas Leces No. 105/Kpts-Up/L/ XI/2010 tanggal 1 November 2010.

Pelaksanaan Program Kemitraan dilakukan dengan cara memberikan bantuan berupa pinjaman untuk membiayai modal usaha, membantu promosi dan pemasaran hasil produksi. Tetapi setelah dilakukan wawancara kepada beberapa mitra binaan, PT Kertas Leces hanya memberikan bantuan berupa modal lunak (soft loan) dengan bunga $6 \%$ pertahun bagi usaha kecil atau menengah yang mempunyai prospek yang baik. Sedangkan bantuan berupa promosi, pemasaran, pembinaan, pelatihan (training) dalam hal untuk memajukan usaha mitra binaan saat ini intensitasnya menurun karena keterbatasan yang ada.

PT Kertas Leces memberi bantuan selain modal usaha seperti pembinaan, promosi, pemasaran, dan lain sebagainya lebih intensif dilakukan pada saat kondisi perusahaan masih normal dulu, artinya kondisi perusahaan pada waktu itu masih beroperasi. Sasaran atau target dalam penerapan Program Kemitraan ini adalah usaha kecil atau calon mitra binaan yang usahanya sudah berjalan minimal satu tahun dan mempunyai prospek yang baik, hal tersebut dapat dilihat dari jumlah aset ataupun tingkat pendapatan usaha calon mitra binaan.

Sub Unit Humas adalah organisasi yang menangani Program Bina Lingkungan. Organisasi ini memiliki program kerja yaitu menciptakan komunikasi internal dan eksternal yang baik, dan melaksanakan pelayanan yang baik dalam rangka mewujudkan Program Community Development (CD). Sedangkan untuk alokasi dana untuk Program Bina Lingkungan adalah sebesar Rp 122.000.000,00. Sasaran atau target dalam penerapan Program Bina Lingkungan adalah serikat pekerja atau para karyawan PT Kertas Leces, instansi terkait, media massa dan masyarakat sekitar perusahaan, selain itu juga agar terlaksananya pelayanan yang baik dalam rangka mewujudkan Program Community Development $(C D)$. Pelaksanaan komunikasi yang baik dengan para karyawan ini dituangkan dalam bentuk Kesepakatan Kerja Bersama PT Kertas Leces (Persero) pada tanggal 15 Juli 2010. Dalam kesepakatan ini terdapat pemenuhan hak dan kewajiban karyawan PT Kertas Leces misalnya pemberian sarana pemeliharaan kesehatan bagi karyawan dan anggota keluarganya, pembentukan Panitia Pembina Keselamatan dan Kesehatan Kerja (PK3) untuk menghindari dan mencegah timbulnya kecelakaan kerja akibat hubungan kerja, selain itu perusahaan menyediakan perlengkapan Keselamatan dan Kesehatan Kerja (K3) bagi karyawan sesuai kebutuhan di bidang atau tugas masingmasing, perusahaan menyelenggarakan program Jaminan Hari Tua kepada karyawan, perusahaan menyediakan Koperasi Karyawan Keluarga Besar Kertas Leces (K4L) dan Yayasan Pendidikan Karyawan dan Keluarga Kertas Leces (YPKK), dan lainlain. Pelaksanaan pelayanan dalam rangka mewujudkan Program Community Development (CD) biasanya diwujudkan dalam bentuk memberdayakan masyarakat sekitar perusahaan dengan memberikan kesempatan bekerja sebagai tenaga kasar di proyek boiler batu ara sesuai kebutuhan proyek, adanya bantuan kepada pemerintah daerah Probolinggo seperti bantuan dana, sarana, dan material dalam rangka Musyawarah Pimpinan Daerah (Muspida) dan Musyawarah Pimpinan Kecamatan (Muspika), adanya sunatan masal dan bantuan sarana ibadah, pemberian bantuan air bersih kepada daerah-daerah di sekitar Probolinggo yang kesulitan air bersih, bantuan irigasi bagi sawah-sawah masyarakat disekitar PT Kertas Leces, dan adanya bantuan penghijauan untuk konservasi air, dan lain-lain.

Dengan adanya Program Corporate Social Responsibility (CSR) atau Program Kemitraan Bina Lingkungan milik PT Kertas Leces maka Output atau Outcome yang diperoleh antara lain: Pertama, adanya pengelolaan lingkungan kerja secara baik dengan terpenuhinya hak-hak para karyawan atau serikat pekerja beserta keluarganya seperti yang tertuang dalam Kesepakatan Kerja Bersama PT Kertas Leces (Persero) pada tanggal 15 Juli 2010. Meskipun keadaan perusahaan masih belum stabil dimana perusahaan mengalami kurang lancar dalam hal berproduksi, tetapi pemenuhan terhadap hak-hak karyawan masih tetap diberlakukan seperti masih adanya sistem penggajian karyawan tiap bulannya, adanya fasilitas kesehatan karyawan beserta keluarganya, masih berjalannya Koperasi Karyawan Keluarga Besar Kertas Leces (K4L) dan Yayasan Pendidikan Karyawan dan Keluarga Kertas Leces (YPKK). 
Kedua, Dengan adanya Program Kemitraan, Usaha Kecil Menengah (UKM) atau mitra binaan yang mendapat bantuan pinjaman lunak dapat mandiri dan berkembang dibanding sebelum mendapatkan bantuan. Seperti yang telah diungkapkan para mitra binaan kepada peneliti bahwa dengan mendapat pinjaman lunak beserta bunga yang ringan dari PT Kertas Leces usaha yang mereka tekuni selama ini menjadi semakin lebih berkembang daripada dulu sebelum mendapat bantuan. Ketiga, dengan adanya penanganan limbah secara baik maka tercipta kelestarian lingkungan di sekitar PT Kertas Leces. Hal ini dibuktikan dengan limbah perusahaan dapat digunakan ulang oleh masyarakat, seperti limbah cair yang dapat digunakan untuk irigasi sawah dan bahkan dapat meningkatkan hasil pertanian para petani di sekitar PT Kertas Leces. Karena kondisi perusahaan saat ini tidak beroperasi maka pengaliran limbah kepada sawah-sawah petani di sekitar perusahaan tidak sebanyak dulu waktu perusahaan masih berproduksi atau beroperasi.

Keempat, adanya investasi sosial PT Kertas Leces kepada masyarakat sekitar dapat menunjang kegiatan bisnis perusahaan, karena dengan investasi sosial perusahaan menuai citra yang positif atau masyarakat memiliki pandangan yang baik terhadap PT Kertas Leces. Investasi sosial ini diwujudkan melalui Community Development ( $C D$ ) oleh PT Kertas Leces. Dengan adanya investasi sosial ini juga memberikan dampak positif bagi masyarakat di sekitar perusahaan diantaranya masyarakat lebih berdaya dan juga pendapatan masyarakat meningkat, karena sebagian masyarakat menjadi karyawan PT Kertas Leces baik itu yang bekerja sebagai tenaga kasar di proyek boiler batu bara sekarang ini maupun yang menjadi pegawai tetap PT Kertas Leces.

Dari analisis mengenai penerapan Corporate Social Responsibility (CSR) atau Program Kemitraan Bina Lingkungan (PKBL) PT Kertas Leces diatas, maka dapat disimpulkan bahwa meskipun keadaan perusahaan belum stabil dimana perusahaan mengalami kurang lancar dalam hal berproduksi, tetapi penerapan Corporate Social Responsibility (CSR) atau yang lebih dikenal Program Kemitraan Bina Lingkungan (PKBL) masih tetap dilakukan oleh perusahaan ini. Jumlah total dana yang dikeluarkan untuk Program Kemitraan pada tahun 2014 dan 2015 adalah Rp 80.000.000,00 dan Rp 47.000.000,00. Sedangkan jumlah total dana yang dikeluarkan untuk Program Bina Lingkungan pada tahun 2014 dan 2015 adalah
Rp 93.748.000,00 dan Rp 40.567.500,00. Dari jumlah besaran dana yang dikeluarkan untuk Program Kemitraan dan Program Bina Lingkungan pada tahun 2014 lebih banyak daripada dana yang dikeluarkan pada tahun 2015. Hal ini sangat dipengaruhi oleh keadaan perusahaan yang belum stabil, dimana harga bahan baku untuk pembuatan kertas sangat tinggi dan mengakibatkan harga jual yang tinggi pula. Situasi yang seperti ini berdampak pada perusahaan yang saat ini mengalami penurunan order atau permintaan dari pihak lain. Meskipun keadaan PT Kertas Leces labil, tetapi hal ini tidak mengurangi tanggung jawab sosial perusahaan PT Kertas Leces terhadap masyarakat dan lingkungan sekitar perusahaan.

Dari penjabaran mengenai penerapan Corporate Social Responsibility (CSR) atau Program Kemitraan Bina Lingkungan (PKBL) pada PT Kertas Leces, maka dapat dikatakan bahwa perusahaan ini belum menerapkan Triple Bottom Line. Didalam Triple Bottom Line terdapat 3 aspek tanggung jawab sosial yaitu tanggung jawab dalam bidang profit (ekonomi), sosial atau masyarakat, dan lingkungan. Tanggung jawab sosial PT Kertas Leces jika dikaitkan dengan konsep Triple Bottom Line maka perusahaan ini hanya memenuhi aspek tanggung jawab kepada sosial atau masyarakat dan tanggung jawab terhadap lingkungan saja. Tanggung jawab dalam bidang profit (ekonomi) adalah bagaimana cara agar para pelaku perusahaan mendatangkan keuntungan yang sebesarbesarnya kepada para shareholders (para pemegang saham).

Dalam kondisi perusahaan seperti sekarang, para pelaku perusahaan belum bisa mendatangkan keuntungan yang sebesar-besarnya kepada para pemegang saham. Hal ini juga dipicu oleh kondisi internal maupun eksternal perusahaan yang masih belum memungkinkan untuk mendapatkan keuntungan atau laba sebanyak-banyakya. Kondisi internal perusahaan seperti kurang bagusnya strategi risk management perusahaan (manajemen resiko) dan kurangnya sumber daya manusia generasi muda, karena dengan adanya generasi muda akan melahirkan banyak pemikiran baru dalam mengatasi masalah perusahaan. Sedangkan kondisi eksternal perusahaan seperti naiknya harga bahan baku produksi yang mengakibatkan harga jual menjadi tinggi dan berdampak pada semakin berkurangnya permintaan dari konsumen.

Berdasarkan penyajian data mengenai penerapan Corporate Social Responsibility (CSR) atau Program Kemitraan Bina Lingkungan (PKBL), 
perusahaan PT Kertas Leces termasuk dalam kategori perusahaan kelompok biru. Perusahaan ini tidak menjadikan Corporate Social Responsibility (CSR) sebagai strategi inti dari jantung bisnisnya tetapi lebih menganggap penerapan Corporate Social Responsibility (CSR) akan memberikan dampak positif terhadap usahanya karena merupakan suatu investasi sosial. Adanya investasi sosial dari PT Kertas Leces sudah cukup untuk menjadi landasan Sustainable Development (Pembangunan Berkelanjutan) bagi masyarakat dan lingkungan sekitar perusahaan.

Islam mempunyai prinsip pertanggungjawaban yang seimbang dalam segala bentuk dan ruang lingkupnya. Antara jiwa dan raga, antara individu dan keluarga, antara individu dan sosial dan, antara suatu masyarakat dengan masyarakat yang lain. Tanggung jawab sosial merujuk pada kewajiban-kewajiban sebuah perusahaan untuk melindungi dan memberi kontribusi kepada masyarakat dimana perusahaan itu berada. Dalam kasus ini jelas terlihat bahwa PT Kertas Leces telah menjelankan fungsi sosialnya dengan baik walaupun ada kekurangan di sana sini tapi tujuan untuk mensejahterakan telah dilaksanakan. Karena dalam perspektif islam sebuah perusahaan yang mengemban tanggung jawab sosial itu melaksanakan fungsi mensejahterakan dalam tiga domain yaitu: Pertama, Pelaku-Pelaku Organisasi, meliputi hubungan perusahaan dengan pekerja, hubungan pekerja dengan perusahaan dan hubungan perusahaan dan pelaku usaha lain; distributor, konsumen, pesaing. Hal ini terkait dengan nilai-nilai dalam Islam yang menjelaskan bahwa dalam pelaksanaan perekonomian itu harus mengedepankan kesejahteraan ekonomi dalam kerangka norma-norma moral Islam; persaudaraan dan keadilan universal; distribusi pendapatan yang adil; dan kebebasan individu dalam konteks kesejahteraan social.

Kedua, lingkungan Alam: Dan janganlah kamu membuat kerusakan di muka bumi, sesudah [Allah] memperbaikinya dan berdo'alah kepadaNya dengan rasa takut [tidak akan diterima] dan harapan [akan dikabulkan]. Sesungguhnya rahmat Allah amat dekat kepada orang-orang yang berbuat baik. (QS. Al-A'raf ayat 56). Tafsir dari ayat diatas adalah bahwa (Dan janganlah kamu membuat kerusakan di muka bumi) dengan melakukan kemusyrikan dan perbuatan-perbuatan maksiat (sesudah Allah memperbaikinya) dengan cara mengutus rasul-rasul (dan berdoalah kepada-Nya dengan rasa takut) terhadap siksaan-Nya (dan dengan penuh harap) terhadap rahmat-Nya. (Sesungguhnya rahmat Allah amat dekat kepada orang-orang yang berbuat baik) yakni orang-orang yang taat.

Jangan kalian membuat kerusakan di muka bumi yang telah dibuat baik dengan menebar kemaksiatan, kezaliman dan permusuhan. Berdoalah kepada-Nya dengan rasa takut akan siksa-Nya dan berharap pahala-Nya. Kasih sayang Allah sangat dekat kepada setiap orang yang berbuat baik, dan pasti terlaksana.

Artinya bahwa dalam pelaksanaan CSR harus mengedepakan penjagaan atas kelestarian alam. Perusahaan tidak boleh mengabaikan hak alam untuk dijaga dengan sebaik-baiknya dan tidak dirusak. Program CSR dari PT Kertas Leces telah menjadikan nilai ini sebagai tujuannya. Atau dengan kata lain PT Kertas Leces sudah sesuai dengan nilai-nilai islam ini.

Prinsip-prinsip mendasar yang membentuk filosofi kebajikan lingkungan yang dilakukan secara holistik oleh Nabi Muhamad SAW adalah keyakinan akan adanya saling ketergantungan di antara makhluk ciptaan Allah. Karena Allah SWT menciptakan alam semesta ini secara terukur, baik kuantitatif maupun kualitatif (lihat QS. Al Qamar: 49) dan dalam kondisi yang seimbang (QS. Al hadid:7). Sifat saling ketergantungan antara makhluk hidup adalah sebuah fitrah dari Allah SWT. Dari prinsip ini maka konsekuensinya adalah jika manusia merusak atau mengabaikan salah satu bagian dari ciptaan Allah SWT, maka alam secara keseluruhan akan mengalami penderitaan yang pada akhirnya juga akan merugikan manusia.

Allah SWT berfirman: "telah nampak kerusakan di darat dan di laut disebabkan karena perbuatan tangan manusi, supaya Allah merasakan kepada mereka sebahagian dari (akibat) perbuatan mereka, agar mereka kembali (ke jalan yang benar." (QS. Ar Rum:41)

Dari penjelasan diatas menunjukan bahwa Islam telah mengatur dengan begitu jelas tentang prinsipprinsip dasar yang terkandung dalam CSR, padahal isu CSR baru dimulai pada abad ke-20. Bahkan dalam berbagai code of conduct yang dibuat oleh beberapa lembaga, Islam telah memberikan penjelasan terlebih dahulu. Misalnya, dalam draft ISO 26000, Global Reporting Initiatives (GRI), UN Global Compact, International Finance Corporation (IFC), dan lainnya telah menegaskan berbagai instrumen indikator bagi pelaksanaan komitmen CSR perusahaan demi pemenuhan target pembangunan berkelanjutan seperti isu lingkungan hidup, hak asasi manusia, praktik 
ketenagakerjaan, perlindungan konsumen, tata kelola perusahaan, praktik operasional yang adil, dan pengembangan masyarakat. Dan bila ditilik lebih lanjut, sebenarnya prinsip-prinsip tersebut merupakan representasi berbagai komitmen yang dapat bersinergi dengan pengamalan prinsip kehidupan Islami.

Ketiga, kesejahteraan sosial masyarakat, konsep kesejahteraan sosial yang dimaksud ini sini adalah bahwa program CSR yang dilakukan PT Kertas Leces mengedepankan konsep Sustainable Development (Pembangunan Berkelanjutan) yang bertujuan untuk pertumbuhan yang mendukung peningkatan pembangunan perekonomian, masyarakat, dan lingkungan. Investasi sosial PT Kertas Leces diwujudkan dalam bentuk Community Development (CD) yang berupa pemberian bantuan berupa dana kepada masyarakat, ikut dalam kegiatan pelestarian lingkungan, dan lain-lain. Hal ini dilakukan agar penerapan Corporate Social Responsibility (CSR) dapat memberikan manfaat positif kepada perusahaan terutama dalam jangka panjang. Selain untuk menegaskan brand differentiation perusahaan, juga merupakan sarana untuk memperoleh licence to operate baik dari pemerintah maupun dari masyarakat sekitar PT Kertas Leces. Tetapi penerapan Corporate Social Responsibility (CSR) atau Program Kemitraan Bina Lingkungan (PKBL) milik PT Kertas Leces ini belum dijadikan sebagai strategi dalam menghadapi resiko perusahaan atau risk management. Pelaksanaan konsep ini sejalan dengan surat Al-Anbiya': 107 “Dan tidaklah Kami mengutus kamu, melainkan untuk (menjadi) rahmat bagi seluruh alam." (Q.S. al-anbiyâ' [21]:107).

Tafsir ayat di atas adalah Kami tidak mengutusmu, wahai Nabi, kecuali sebagai perwujudan kasih sayang yang menyeluruh untuk alam semesta. Selanjutnya, Allah memuji Rasul-Nya yang datang membawa Al Qur'an. Diutus-Nya Beliau adalah rahmat bagi alam semesta. Orang-orang mukmin menerima rahmat itu dan mensyukurinya, oleh karenanya mereka membenarkan Beliau, sedangkan selain mereka kufur terhadap nikmat itu dan menggantinya dengan kekafiran serta menolak rahmat tersebut.

Artinya agama islam dijadikan kerangka referensial ataupun sebagai problem solver (penyelesai masalah) atas kondisi masyarakat atau bangsa saat ini. menurut hemat penulis, islam dalam menjawab dan menawarkan solusi terhadap ralitas sosial yang ada bisa dilihat dari dua aspek, pertama, aspek doktrinasi (ajarannya), yaitu Islam memerintahkan dan mewajibkan kepada umat manusia untuk selalu melakukan kebajikan dan saling membantu serta saling berbagi terhadap sesamanya ketika mengalami kesulitan dan masalah dalam hidupnya. seperti islam mewajibkan umat manusia untuk membantu orang miskin, anak yatim, orang peminta-minta dan orang yang ada di perjalanan (musafir), sebagaimana Allah Swt berfirman dalamAl-qur' an Surah Al-baqarah:17. Kedua, aspek kerangka aksiologis, artinya dalam pemahaman ajaran islam mempunyai unsur nilai dan etika di dalamnya. Nilai menjadi landasan berpijak dan motivasi moral umat manusia dalam melakukan suatu perubahan dan kebaikan dalam kehidupan sosialnya yang berprinsip pada nilai-nilai kemanusian, sedangkan etika menjadi tindakan proyeksitas umat manusia dalam menyelesaikan segala masalah sosial yang dihadapinya. Seperti halnya Etika sosial merupakan cerminan sebuah rasa kepedulian antar sesama manusia atau sesama anak bangsa, dan Etika keadilan yang mencerminkan pada keseimbangan dalam hidup terutama dalam hal kepemilikan materil. Hal ini bisa kita dengan adanya konsep Zakat yang menjadi ajaran pokok dalam Islam. Adanya praktek zakat dalam Islam tidak hanya menjalankan sebuah kewajiban saja, tetapi hal itu merupakan cerminan sebuah etika sosial dan etika keadilan Islam dalam rangka mewujudkan masyarakat yang sejahtera.

Kedua aspek tersebut merupakan salah bentuk upaya dan spirit agama islam dalam menjawab realitas sosial yang ada saat ini seperti kemiskinan, gelandangan, dll yang ada di tengah-tengah masyarakat kita. Islam menginginkan masyarakat yang sejahtera. Sebagaimana defenisi sederhana masyarakat sejahtera dalam studi kesejahteraan sosial yaitu kondisi terpenuhinya kebutuhan materil, spritual, dan sosial warga negara agar dapat hidup layak dan mampu mengembangkan diri, sehingga dapat melaksanakan fungsi sosialnya.

Artinya bahwa dalam pelaksanaan CSR harus mengedepakan kesejahteraan social bagi pekerja dan lingkungannya sudah sesuai dengan nilai ini. Perusahaan tidak mengabaikan hak orang lain untuk sejahtera. Program CSR dari PT Kertas Leces telah menjadikan nilai ini sebagai tujuannya. Atau dengan kata lain PT Kertas Leces sudah sesuai dengan nilai-nilai Islam ini.

\section{KESIMPULAN}

Berdasarkan apa yang diungkapkan di atas maka dapat disimpulkan beberapa hal berikut: (1) Organisasi pelaksana program Corporate Social Responsibility 
(CSR) penerapan Corporate Social Responsibility $(C S R)$ atau Program Kemitraan Bina Lingkungan (PKBL) dibagi menjadi dua bagian yaitu Departemen Penelitian dan Pengembangan (Litbang) menangani Program Kemitraan, sedangkan Sub Unit Hubungan Masyarakat (Humas) menangani Program Bina Lingkungan; (2) Sasaran atau target program Corporate Social Responsibility (CSR) PT Kertas Leces dibagi menjadi dua bagian yaitu sasaran atau target dalam penerapan Program Kemitraan adalah usaha kecil atau calon mitra binaan yang usahanya sudah berjalan (minimal satu tahun), sedangkan sasaran atau target dalam penerapan Program Bina Lingkungan adalah masyarakat sekitar perusahaan, serikat pekerja atau para karyawan PT Kertas Leces, instansi terkait, dan media massa; (3) Output atau outcome program Corporate Social Responsibility (CSR) atau Program Kemitraan Bina Lingkungan (PKBL) PT Kertas Leces ini adalah adanya pengelolaan lingkungan kerja maka terpenuhi hak-hak para karyawan beserta keluarganya, Usaha Kecil Menengah (UKM) atau mitra binaan yang mendapat bantuan pinjaman lunak dapat mandiri dan berkembang, adanya penanganan limbah secara baik maka tercipta kelestarian lingkungan di sekitar PT Kertas Leces, dan adanya investasi sosial PT Kertas Leces kepada masyarakat disekitar; dan (4) Dalam perspektif islam apa yang dilakukan oleh PT Kertas Leces sudah sesuai yaitu dilihat dari nilai-nilai (a) penjagaan terhadap lingkungan dan melestarikannya; (b) upaya untuk menghapus kemiskinan; (c) mendahulukan sesuatu yang bermoral bersih daripada sesuatu yang secara moral kotor, walaupun mendatangkan keuntungan yang lebih besar; dan (d) jujur dan amanah.

\section{DAFTAR RUJUKAN}

Moleong, J. Lexy. 2000. Metode Penelitian Kualitatif. Bandung: PT Rosdakarya.

Kartini, Dwi. 2009. Corporate Social Responsibility: Transformasi Konsep Sustainability Management dan Implementasi di Indonesia. Bandung: PT Rafika Aditama

Wahyudi, Isa dan Azheri, Busyra. 2008. Corporate Social Responsibility: Prinsip, Peraturan dan Implementasi. Malang: In-Trans Publishing.

Wibisono, Yusuf. 2007. Membedah Konsep dan Aplikasi Corporate Social Responsibility. Cetakan 1. Gresik: Fascho Publishing. 